\title{
Effect of Some Household Products (Kerosene, Insecticide and Perfume) on Arthropods Colonization on Rats' Cadavers
}

\author{
Nagwa M. Ghandour ${ }^{1}$ and Rasha A. H. Attia ${ }^{2}$
}

${ }^{1}$ Department of Forensic Medicine and Clinical Toxicology
${ }^{2}$ Department of Medical Parasitology

Faculty of Medicine, Assiut University, Assiut, Egypt

Corresponding author

Nagwa M. Ghandour

E-mail:n_ghandour10@yahoo.com

\begin{abstract}
The most common task of a forensic entomologist is to determine an accurate minimum post-mortem interval (PMI) using necrophagous fly larvae found on carrion. The presence of repellent substances on cadaver is not generally well informed and can be difficult to detect. This study aimed to evaluate the effect of some common household products (kerosene, insecticide, perfume) on arthropods colonization on rats' cadavers including their effect on the type of species, and first insect's arrival time. As well as relation of the stage of decomposition to both the type of species and first insect's arrival time. The experiment was performed during spring season. Twenty healthy rat carrions $(200 \pm 50 \mathrm{~g})$ were randomly divided into four groups; each group was consisted of five rats. Group (1) served as a control, was kept without any substance poured on it. Group 2, Kerosene poured rats, where kerosene was splashed on each rat. Group 3, Insecticide poured rats, where flying insects killer was splashed on each rat. Lastly, $4^{\text {th }}$ group, Perfume poured rats, where perfume was splashed on each one. The presence of arthropods was checked at regular intervals during the period of experiment. The use of these products didn't only affect the time of first insect's arrival but also type of insects and stage of decomposition. In control group, during the fresh stage of decomposition, the first insects appeared and the most abundant orders were Diptera of families Sarcophagidae, Calliphoridae and Muscidae, followed by Coleoptera (Dermestidae) during the bloat and wet decomposition stages. All presented species were collected from the control group, while Musca domestica and Dermestes frischii didn't appear in any of the poured cadavers (Groups $2,3,4)$ till the end of the experiment. Colonisation delay was for $(96.5 \mathrm{~h} \pm 0.55)$ in rats of group (2), (3.5 h \pm 0.3$)$ in rats of group (3) and (4.5 $\mathrm{h} \pm$ S.D. 0.4) in rats of group (4). Distinct delay in decomposition stages was observed in kerosene poured rats (Group 2. These results together confirm the repellent effect of some household products on flies and the necessity for forensic entomologists to consider this hypothesis when estimating the PMI.
\end{abstract}

Keywords Forensic entomology; postmortem interval; flies

\section{Introduction}

$\mathrm{F}$ orensic or medicolegal entomology is the study of insects associated with a dead body, primarily to estimate minimum elapsed time since death or minimum postmortem interval (PMI) (VanLaerhoven, 2008).

Campobasso et al. (2001) stated that the entomological method statistically more reliable and superior in estimation of postmortem interval when compared to other prevalent procedures such as the medicolegal method based only on the classical postmortem changes in soft tissues (hypostasis, rigor mortis, body cooling, autolysis and decomposition).

Certain species of insects are often the first witnesses to a crime. They usually arrive within 24 hours of death if the season is suitable i.e. spring, summer and can arrive within minutes in the presence of blood or other body fluids (Anderson, 1998). 
The usual classification of sarcosaprophagous fauna divides them into five distinct ecological groups: necrophagous, necrophilous, omnivorous, opportunists and accidentals. In general, necrophages, necrophils and omnivores are the most important for forensic purpose (Arnaldos et al., 2005).

Necrophages insects are the major vector in the degradation of the cadaver because of their elevated numbers and first colonizers of carrion. The necrophages insect category was made up of Diptera (flies) and Coleoptera (beetles). These two insect orders stand out among the others for their activity and frequency on human remains (Segura et al., 2009).

Insects feed on carrion in a successional manner dependent on the state of decomposition (Wolff et al., 2001). Arthropod succession analysis allows the association of each species or group to a well established decomposition stage [i.e. fresh, bloat, wet decomposition, dry decomposition or skeletal stage] (Campobasso et al., 2001; Abd El-bar and Sawaby, 2011).

The forensic entomologist is responsible for determining the period of insect activity according to all the variables affecting insect invasion of remains and their development. Also, the knowledge of factors inhibiting or favoring colonization and development of Diptera is a necessary pre-requisite for estimating the PMI using entomological data (Campobasso and Introna, 2001).

The attraction of large numbers of adult blowflies occurs as a result of decay, which are mainly due to bacterial action on dead tissues (Varatharajan and Sen, 2000). Their strategy on attraction is based on precise odour mediated location (Gibson and Torr, 1999). The presence of repellent substances on carrion is not generally well informed and can be difficult to detect. These substances could be used by murderers to conceal the smell of a cadaver or to prevent insect colonization. Such products can result both in a delayed colonization and/or the absence of the earliest necrophagous species. Thus, repellents can lead to an under-estimation of PMI by the wrong interpretation of the age or composition of species found on a corpse (Campobasso et al., 2001).

In Egypt, especially Assiut City, studies on carrion arthropods are very few, and the evaluation of entomological evidence in forensic cases is based on studies carried out in other biogeographical areas with different environmental conditions.

The present study, conducted under field conditions, aimed to evaluate the effect of some common household products (kerosene, insecticide and perfume) on necrophagous insects, including their effect on the type of species, and first insect's arrival time. The relation of stage of decomposition to both the type of species and first insect's arrival time is also studied.

\section{Material and methods}

\section{Material}

1- Kerosene was obtained from local gas distributor.

2- Insecticide (Trade name: New Pyrosol Flying Insects Killer). Contents : New-Pynamin forte $0.2 \%$, Sumethrin $0.075 \%$, Iso-propyl alcohol $0.26 \%$, Perfume $0.52 \%$, Kerosene $41.055 \%$, Propane/Butane $57.89 \%$ ). Produced by ElNasr Co. for Intermediate Chemicals. Egypt.

3- Perfume (Trade name: Request. Eau de Cologne). Contents: Ethanol 70\%and Essential oil 30\%. Produced by Kesma Group. Egypt.

\section{Site description}

The study was carried out in Assiut City, Capital of Assiut Governorate, located $375 \mathrm{~km}$ South to Cairo. Assiut Governorate is known to present in the Great Desert region. Assiut City, geographical position ranges from longitude $30^{\circ} 45^{\prime}$ to $31^{\circ} 27^{\prime}$ east and from latitude $26^{\circ} 45^{\prime}$ to $27^{\circ} 45^{\prime}$ north. The study was located in Assiut University campus ( $\left.31^{\circ} 09^{\prime} \mathrm{E}, 27^{\circ} 11^{\prime} \mathrm{N}\right)$ about $2 \mathrm{~km}$ north to city centre. Elevation of the study site was 39 meter above the sea level and 15 meter above the ground level. Coordinates and elevation of the study site were taken on the day of placement with handheld GPS unit (e-trex vista, Garmin corp., Olathe, KS) .The average maximum temperature for spring in Assiut is $31.3{ }^{\circ} \mathrm{C}$ while the average relative humidity is $28 \%$ for spring (Moatamed, 2005). Daily weather data (mean of maximum and minimum temperature and relative humidity) were acquired from the Egyptian Meteorological Authority, Assiut station in the University campus.

\section{Experiment}

The experimental procedure was carried out according to the National Institute of Health Guidelines for Animal Care followed within the Faculty of Medicine, Assiut University. Experiment was carried out on the roof of the Faculty of Medicine, in an area with an all day length sun exposure and sheltered from wind. The experiment was started at $24^{\text {th }}$ March 2010 and stopped at the end of $30^{\text {th }}$ March. Twenty healthy rat carrions (Rattus norvegicus, $200 \pm 50 \mathrm{~g}$ ) were obtained from animal house of the Faculty of Medicine, and were randomly divided into four groups; each group was consisted of five rats. They were killed by cervical decapitation after ether inhalation anaethesia. As described by Charabidze et al. (2009), each rat was placed in a separate transparent covered plastic box $(100 \mathrm{~cm} \times 80 \mathrm{~cm} \times 15 \mathrm{~cm})$. Both lateral sides of the box were replaced by plastic nets $(1 \mathrm{~cm} \times 1 \mathrm{~cm})$ to allow access of insects. The bottom was covered with sand of $10 \mathrm{~cm}$ height, in order to absorb putrid liquids. All boxes were separated from each other by a minimum of 20 meters in order to minimize interaction of the 
odors. Common household products (kerosene, insecticide and perfume) were chosen regarding the type generally available in a house, taking into consideration the differences between the skin surface areas of rat and human cadavers. The experimental groups were dealt with as mentioned by Charabidze et al. (2009), in the following order: The $1^{\text {st }}$ group of rats $(n=5)$, Group 1, served as a control, and was kept without any substance was poured on it. The $2^{\text {nd }}$ group of rats ( $n=5)$, Group 2, Kerosene poured rats, where 30 $\mathrm{ml}$ kerosene was splashed on each rat. The $3^{\text {rd }}$ group of rats $(\mathrm{n}=5)$, Group 3, Insecticide poured rats, where 15 $\mathrm{ml}$ of flying insects killer was splashed on each rat. The $4^{\text {th }}$ group of rats $(n=5)$, Group 4, Perfume poured rats, where $3 \mathrm{ml}$ of perfume extract was splashed on each one.

Observations of the species of insects, the first time of insect's arrival as well as decomposition stages were reported. Observations were reported, after placing the rats on the roof, every 15 min during the first hour; every hour for 8 hours and then daily every hour from 8 am to $5 \mathrm{pm}$ till the end of the experiment. With each observation, any insect present in any box was collected. Flying insects were captured by an aerial net while crawling species were collected with a forceps. All collected insects were killed by ethyl acetate and placed in numbered and dated vials containing $70 \%$ alcohol until further identification (Centeno et al., 2002). All Collected flies were identified according to specific keys mentioned in Greenberg (1971); Mosallam (1980); Shaumar et al. (1989); Wells et al. (1999). Genus or species of adult beetles were identified according to Arnett et al. (1980); Yones et al. (2010).

\section{Statistical analysis}

The time of arrival was expressed as mean value \pm standard deviation (SD). To assess statistical significance, Student's t-test was used to compare data between groups. A measured level of $\mathrm{p}<0.05$ was considered significant.

\section{Results}

Regarding the species; five genera of insects representing two orders and four families were found to be coexisted during the experiment. Family Sarcophagidae represented by Sarcophaga haemorrhoidals and Wolhfahrtia sp., family Calliphoridae represented by Chrysomya albiceps, family Muscidae represented by Musca domestica and family Dermestidae represented by adult beetles of Dermestes frischii (Figure 1).

Figure (2) demonstrates the arrival time of the first necrophagous insects on all rats' cadavers. For control rats (Group 1), first arthropod appeared within half an hour $( \pm$ S.D. $=0.10 \mathrm{~h})$. When household products were placed on the rats' cadavers, they induced a significant ( $\mathrm{p} \leq 0.001$ in groups $2,3,4)$ delay in the arrival time of arthropods on carrion i.e. the first insects appeared later compared to the controls. Colonisation delay was for $96.5 \mathrm{~h}( \pm$ S.D. $=0.55 \mathrm{~h})$ in kerosene poured rats (Group 2), $3.5 \mathrm{~h}( \pm$ S.D. $=0.3 \mathrm{~h})$ in insecticide poured rats (Group 3$)$ and $4.5 \mathrm{~h}( \pm$ S.D. $=$ $0.4 \mathrm{~h}$ ) in perfume poured rats (Group 4).

All presented species were collected from the control group. Sarcophaga haemorrhoidals and Wolhfahrtia sp were collected from kerosene poured rats (Group 2), Sarcophaga haemorrhoidals, Chrysomya albiceps and Wolhfahrtia sp were captured from insecticide poured rats (Group 3). While Sarcophaga haemorrhoidals and Chrysomya albiceps were collected from perfume poured rats (Group 4). Musca domestica and Dermestes frischii didn't appear in any of the poured cadavers (Groups 2,3,4) till the end of the experiment (Table 1, Figure 3).

Numbers and time of arrival of each insect species appeared in all groups are suumarized in (Tables 2-5) and (Figures 4-7).

As regarding the decomposition; three observable stages of decomposition were recognized in all rats' cadavers: fresh, bloat, and wet decomposition during the duration of experiment (Table 6). The insects attracted during various stages of decomposition in all experimental cadavers were reported (Table 7$)$. The fresh decomposition stage $\left(1^{\text {st }}\right.$ day), manifested by discoloration of skin and first appearance of Sarcophaga haemorrhoidals in control and groups 3,4. While Chrysomya albiceps appeared in rats control and group 3, and Musca domestica in control rats only. This stage delayed in appearance to $2^{\text {nd }}$ day in kerosene poured rats (Group 2) without appearance of any insect. The bloat decomposition stage $\left(2^{\text {nd }}, 3^{\text {rd }}\right.$ days $)$, characterized by body swelling and inflation, which was obvious in group 1 and gradual in groups 3,4 . This stage delayed in group 2 to the $5^{\text {th }}$ day. Continuation of appearance of Sarcophaga haemorrhoidals in control rat, appearance of Wolhfahrtia in control group and groups 2, 3, Chrysomya albiceps appeared in control group and group 3, while Musca domestica and Dermestes frischii were found in control rats only. The wet decomposition stage ( $4^{\text {th }}$ to $6^{\text {th }}$ days), liquefaction was observed in rats of control and groups 3,4, with continuation the appearance of Sarcophaga haemorrhoidals ,Musca domestica and Dermestes frischii in control rats only and Chrysomya albiceps in rats of groups 3,4.This stage has not been observed in rats of group 2 . 
Table (1): First arrival time of each insect species in all groups during the experiment in Assiut (Egypt).

\begin{tabular}{|c|c|c|c|c|c|c|c|}
\hline & \multirow{2}{*}{\begin{tabular}{|c|}
$\begin{array}{c}\text { Group (1) } \\
\text { Control }(n=5)\end{array}$ \\
Mean \pm SD \\
\end{tabular}} & \multicolumn{2}{|c|}{$\begin{array}{l}\text { Group (2) } \\
\text { Rats poured with } \\
\text { kerosene }(n=5)\end{array}$} & \multicolumn{2}{|c|}{$\begin{array}{l}\text { Group (3) } \\
\text { Rats poured with } \\
\text { insecticide }(n=5)\end{array}$} & \multicolumn{2}{|c|}{$\begin{array}{l}\text { Group (4) } \\
\text { Rats poured with perfume }(n=5)\end{array}$} \\
\hline & & Mean \pm SD & $P$ & Mean \pm SD & $P$ & Mean \pm SD & $P$ \\
\hline Sarcophaga & $0.5 \pm 0.1$ & $96.5 \pm 0.55$ & $0.001^{*}$ & $3.5 \pm 0.30$ & $\begin{array}{l}0.001^{*} \\
0.001^{\#}\end{array}$ & $4.5 \pm 0.40$ & $\begin{array}{l}0.001^{*} \\
0.001^{\#} \\
0.005^{@}\end{array}$ \\
\hline Chrysomya & $3.5 \pm 0.45$ & & & $5.5 \pm 0.55$ & $0.001^{*}$ & $99.5 \pm 0.55$ & $0.001^{*} 0.001^{@}$ \\
\hline Musca domestica & $6.4 \pm 0.37$ & & & & & & \\
\hline Wolhfahrtia & $26.4 \pm 0.55$ & $97.5 \pm 0.55$ & $0.001^{*}$ & $26.2 \pm 0.45$ & $\begin{array}{l}0.546^{*} \\
0.001^{\#}\end{array}$ & & \\
\hline Dermestes & $27.7 \pm 0.38$ & & & & & & \\
\hline
\end{tabular}

${ }^{*}$ P. Probability of significance has been performed for each group referred to control.

${ }^{\#}$ P. Probability of significance has been performed for each group referred to kerosene group.

${ }^{\circledR}$ P. Probability of significance has been performed for each group referred to insecticide group.

Table (2): Numbers and time of arrival of each insect species appeared in control (Group 1).

\begin{tabular}{|c|c|c|c|c|c|c|c|c|c|c|c|c|}
\hline \multirow[b]{2}{*}{ Group (1) } & \multicolumn{2}{|c|}{ First day } & \multicolumn{2}{|c|}{ Second day } & \multicolumn{2}{|c|}{ Third day } & \multicolumn{2}{|c|}{ Fourth day } & \multicolumn{2}{|r|}{ Fifth day } & \multicolumn{2}{|r|}{ Six day } \\
\hline & $\mathrm{n}$ & Mean \pm SD & $\mathrm{n}$ & Mean \pm SD & $\mathrm{n}$ & $\begin{array}{c}\text { Mean } \pm \\
\text { SD }\end{array}$ & $\mathrm{n}$ & Mean \pm SD & $\mathrm{n}$ & Mean \pm SD & $n$ & Mean \pm SD \\
\hline Sarcophaga & 6 & $0.5 \pm 0.2$ & 8 & $26.5 \pm 0.5$ & 0 & 0 & 13 & $75.5 \pm 0.55$ & 0 & 0 & 5 & $124 \pm 0.45$ \\
\hline Chrysomya & 13 & $3.5 \pm 0.42$ & 34 & $26 \pm 0.3$ & 10 & $54.5 \pm 0.55$ & 0 & 0 & 0 & 0 & 0 & 0 \\
\hline Musca domestica & 10 & $6.5 \pm 0.35$ & 0 & 0 & 23 & $54.5 \pm 0.55$ & 5 & $76.5 \pm 0.55$ & 6 & $99.5+ \pm 0.55$ & 6 & $123 \pm 0.45$ \\
\hline Wolhfahrtia & 0 & 0 & 5 & $26.5 \pm 0.55$ & 0 & 0 & 0 & 0 & 0 & 0 & 0 & 0 \\
\hline Dermestes & 0 & 0 & 5 & $28 \pm 0.27$ & 0 & 0 & 5 & $78.5 \pm 0.55$ & 0 & 0 & 0 & 0 \\
\hline
\end{tabular}

$n=$ Total numbers; Mean= mean of time of arrival.

Table (3): Numbers and time of arrival of each insect species appeared in kerosene poured rats (Group 2).

\begin{tabular}{|c|c|c|c|c|c|c|c|c|c|c|c|c|}
\hline \multirow[b]{2}{*}{ Group (2) } & \multicolumn{2}{|r|}{ First day } & \multicolumn{2}{|c|}{ Second day } & \multicolumn{2}{|c|}{ Third day } & \multicolumn{2}{|r|}{ Fourth day } & \multicolumn{2}{|r|}{ Fifth day } & \multicolumn{2}{|r|}{ Six day } \\
\hline & $\mathrm{n}$ & Mean \pm SD & $\mathrm{n}$ & Mean \pm SD & $\mathrm{n}$ & $\begin{array}{c}\text { Mean } \pm \\
\text { SD }\end{array}$ & $\mathrm{n}$ & Mean \pm SD & $\mathrm{n}$ & Mean \pm SD & $n$ & Mean \pm SD \\
\hline Sarcophaga & 0 & 0 & 0 & 0 & 0 & 0 & 0 & 0 & 6 & $96.5 \pm 0.55$ & 0 & 0 \\
\hline Chrysomya & 0 & 0 & 0 & 0 & 0 & 0 & 0 & 0 & 0 & & 0 & 0 \\
\hline Musca domestica & 0 & 0 & 0 & 0 & 0 & 0 & 0 & 0 & 0 & & 0 & 0 \\
\hline Wolhfahrtia & 0 & 0 & 0 & 0 & 0 & 0 & 0 & 0 & 6 & $97.5 \pm 0.55$ & 0 & 0 \\
\hline Dermestes & 0 & 0 & 0 & 0 & 0 & 0 & 0 & 0 & 0 & & 0 & 0 \\
\hline
\end{tabular}

$n=$ Total numbers; Mean= mean of time of arrival.

Table (4): Numbers and time of arrival of each insect species appeared in insecticide poured rats (Group 3).

\begin{tabular}{|c|c|c|c|c|c|c|c|c|c|c|c|c|}
\hline \multirow[b]{2}{*}{ Group (3) } & \multicolumn{2}{|c|}{ First day } & \multicolumn{2}{|c|}{ Second day } & \multicolumn{2}{|c|}{ Third day } & \multicolumn{2}{|c|}{ Fourth day } & \multicolumn{2}{|r|}{ Fifth day } & \multicolumn{2}{|r|}{ Six day } \\
\hline & $\mathrm{n}$ & Mean \pm SD & $\mathrm{n}$ & Mean \pm SD & $\mathrm{n}$ & $\begin{array}{c}\text { Mean } \pm \\
\text { SD }\end{array}$ & $\mathrm{n}$ & Mean \pm SD & $n$ & Mean \pm SD & $\mathrm{n}$ & Mean \pm SD \\
\hline Sarcophaga & 10 & $3.5 \pm 0.3$ & 0 & 0 & 0 & 0 & 0 & 0 & 0 & 0 & 0 & 0 \\
\hline Chrysomya & 23 & $5.5 \pm 0.55$ & 5 & $24.5 \pm 0.55$ & 0 & 0 & 0 & 0 & 5 & $99.5 \pm 0.55$ & 0 & 0 \\
\hline Musca domestica & 0 & 0 & 0 & 0 & 0 & 0 & 0 & 0 & 0 & 0 & 0 & 0 \\
\hline Wolhfahrtia & 0 & 0 & 8 & $26 \pm 0.45$ & 0 & 0 & 0 & 0 & 0 & 0 & 0 & 0 \\
\hline Dermestes & 0 & 0 & 0 & & 0 & 0 & 0 & 0 & 0 & 0 & 0 & 0 \\
\hline
\end{tabular}

$n=$ Total numbers; Mean= mean of time of arrival.

Table (5): Numbers and time of arrival of each insect species appeared in perfumed poured rats (Group 4).

\begin{tabular}{|c|c|c|c|c|c|c|c|c|c|c|c|c|}
\hline \multirow[b]{2}{*}{ Group (4) } & \multicolumn{2}{|c|}{ First day } & \multicolumn{2}{|c|}{ Second day } & \multicolumn{2}{|c|}{ Third day } & \multicolumn{2}{|c|}{ Fourth day } & \multicolumn{2}{|r|}{ Fifth day } & \multicolumn{2}{|r|}{ Six day } \\
\hline & $\mathrm{n}$ & Mean \pm SD & $\mathrm{n}$ & Mean \pm SD & $\mathrm{n}$ & $\begin{array}{c}\text { Mean } \pm \\
\text { SD }\end{array}$ & $\mathrm{n}$ & Mean \pm SD & $\mathrm{n}$ & Mean \pm SD & $\mathrm{n}$ & Mean \pm SD \\
\hline Sarcophaga & 6 & $4.5 \pm 0.40$ & 6 & $26.5 \pm 0.5$ & 0 & 0 & 0 & 0 & 0 & 0 & 0 & 0 \\
\hline Chrysomya & 0 & 0 & 0 & 0 & 0 & 0 & 0 & 0 & 5 & $99.5 \pm 0.55$ & 0 & 0 \\
\hline Musca domestica & 0 & 0 & 0 & 0 & 0 & 0 & 0 & 0 & 0 & 0 & 0 & 0 \\
\hline Wolhfahrtia & 0 & 0 & 0 & 0 & 0 & 0 & 0 & 0 & 0 & 0 & 0 & 0 \\
\hline Dermestes & 0 & 0 & 0 & 0 & 0 & 0 & 0 & 0 & 0 & 0 & 0 & 0 \\
\hline
\end{tabular}

$n=$ Total numbers; Mean= mean of time of arrival. 
Table (6): Decomposition (stages and duration) during the experiment.

\begin{tabular}{|l|l|l|l|l|}
\hline \multicolumn{1}{|c|}{$\begin{array}{c}\text { Stage of decomposition } \\
\text { (days post death) }\end{array}$} & \multicolumn{1}{|c|}{$\begin{array}{c}\text { Group (1) } \\
\text { Control }\end{array}$} & $\begin{array}{c}\text { Group (2) } \\
\text { Rats poured with } \\
\text { kerosene }\end{array}$ & $\begin{array}{c}\text { Group (3) } \\
\text { Rats poured with } \\
\text { insecticide }\end{array}$ & $\begin{array}{c}\text { Group (4) } \\
\text { Rats poured with } \\
\text { perfume }\end{array}$ \\
\hline $\begin{array}{l}\text { Fresh }(0-1) \\
\text { Discoloration of skin }\end{array}$ & Late to $2^{\text {nd }}$ day & & \\
\hline $\begin{array}{l}\text { Bloat }(>1-3) \\
\text { Body swelling and inflation }\end{array}$ & $\begin{array}{l}\text { More obvious body } \\
\text { swelling and inflation }\end{array}$ & $\begin{array}{l}\text { Late manifested till } \\
\text { the } 5^{\text {th }} \text { day }\end{array}$ & $\begin{array}{l}\text { Gradual inflation } \\
\text { then deflation }\end{array}$ & $\begin{array}{l}\text { Gradual inflation } \\
\text { then deflation }\end{array}$ \\
\hline $\begin{array}{l}\text { Wet decomposition } \\
(>4-6)\end{array}$ & Fluid leakage & Fluid leakage & Fluid leakage \\
\hline
\end{tabular}

Table (7): Entomofauna attracted during various stages of rat carcasses decomposition.

\begin{tabular}{|c|c|c|c|c|c|c|c|c|c|c|c|c|c|c|}
\hline \multirow[t]{3}{*}{ Order } & \multirow[t]{3}{*}{ Family } & \multirow[t]{3}{*}{ Genus } & \multicolumn{3}{|c|}{$\begin{array}{c}\text { Group (1) } \\
\text { Control } \\
(n=5)\end{array}$} & \multicolumn{3}{|c|}{$\begin{array}{l}\text { Group (2) } \\
\text { Rats poured } \\
\text { with } \\
\text { kerosene } \\
(n=5)\end{array}$} & \multicolumn{3}{|c|}{$\begin{array}{l}\text { Group (3) } \\
\text { Rats poured } \\
\text { with } \\
\text { insecticide } \\
(n=5)\end{array}$} & \multicolumn{3}{|c|}{$\begin{array}{c}\text { Group (4) } \\
\text { Rats poured } \\
\text { with perfume } \\
\qquad(n=5)\end{array}$} \\
\hline & & & $\mathrm{F}$ & $\mathrm{B}$ & $\mathrm{W}$ & $\mathrm{F}$ & $\mathrm{B}$ & $\mathrm{W}$ & $\mathrm{F}$ & $\mathrm{B}$ & $\mathrm{W}$ & $\mathrm{F}$ & $\mathrm{B}$ & $\mathrm{W}$ \\
\hline & & & \begin{tabular}{|l|}
$0-1$ \\
$d$
\end{tabular} & \begin{tabular}{|l|}
$2-3$ \\
$d$
\end{tabular} & $\begin{array}{l}4-6 \\
d\end{array}$ & $\begin{array}{l}0-3 \\
d\end{array}$ & $\begin{array}{l}4-6 \\
d\end{array}$ & & $\begin{array}{l}0-1 \\
d\end{array}$ & $\begin{array}{l}2-3 \\
d\end{array}$ & $\begin{array}{l}4-6 \\
d\end{array}$ & $\begin{array}{l}0-1 \\
d\end{array}$ & $\begin{array}{l}2-3 \\
d\end{array}$ & $\begin{array}{l}4-6 \\
d\end{array}$ \\
\hline Diptera (flies) & Sarcophagidae & \begin{tabular}{|l} 
Sarcophaga \\
haemorroidals
\end{tabular} & & & & & & & & & & & & \\
\hline & & Wolhfahrtia sp. & & & & & & & & & & & & \\
\hline & Calliphoridae & Chrysomya albiceps & & & & & & & & & & & & \\
\hline & Muscidae & Musca domestica & & & & & & & & & & & & \\
\hline $\begin{array}{l}\text { Coleoptera } \\
\text { (beetles) }\end{array}$ & Dermestidae & $\begin{array}{l}\text { Dermestis } \\
\text { frischii }\end{array}$ & & & & & & & & & & & & \\
\hline
\end{tabular}

$F$, fresh; B, bloat; $W$, wet decomposition; d' day.
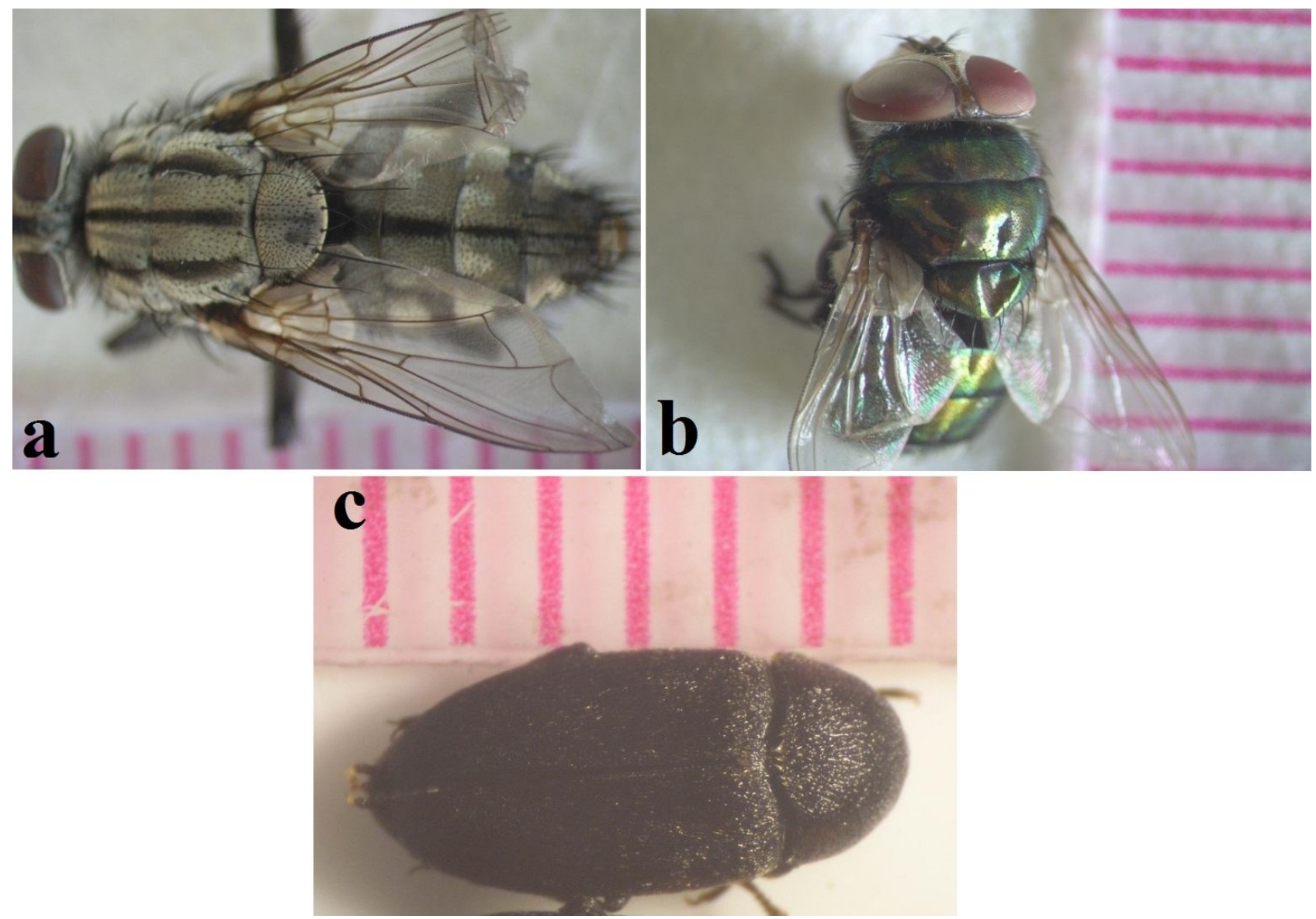

Figure (1): Photos of some species of arthropods appeared in rats' cadavers of the experiment in Assiut (Egypt); a, Sarcophaga haemorrhoidals; b, Chrysomya albiceps; c, Dermestes frischii. 


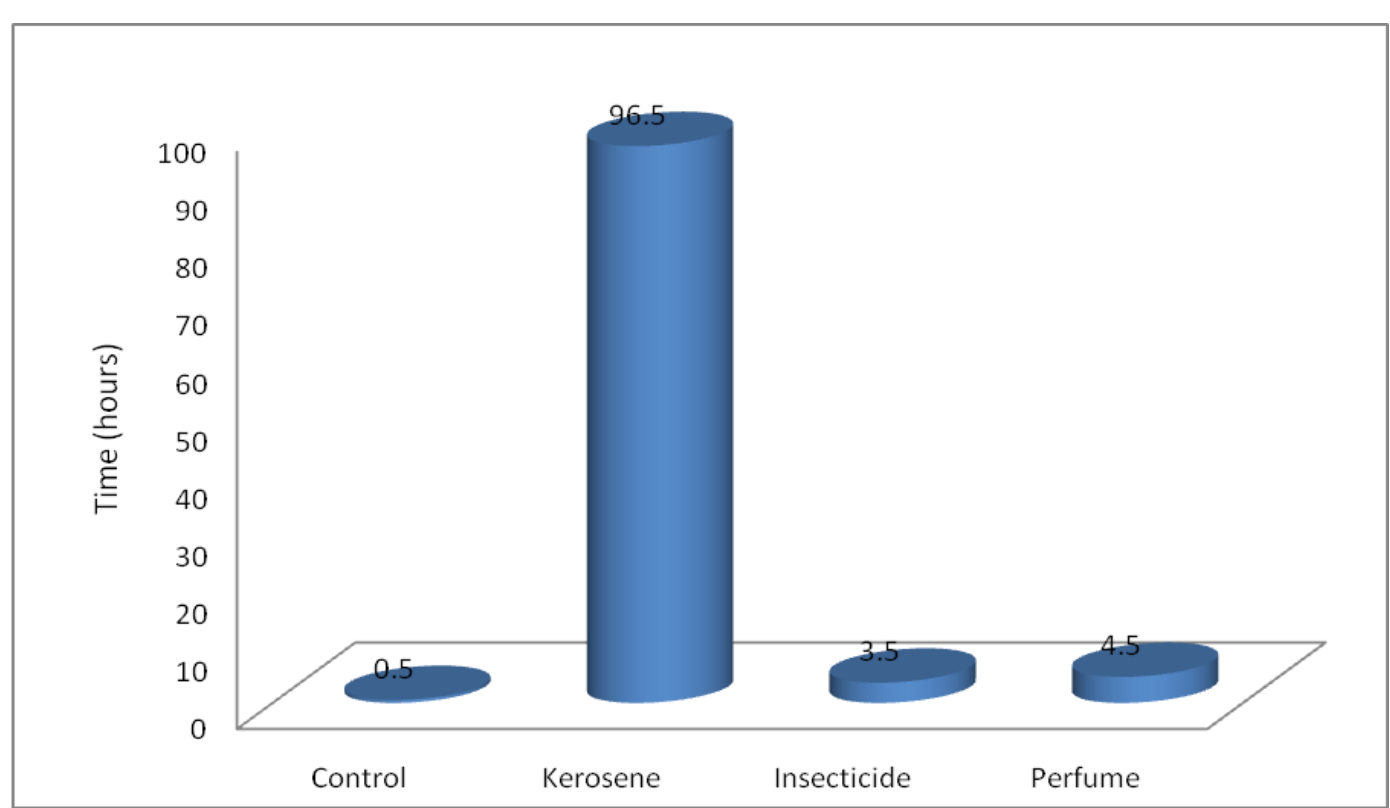

Figure (2): Arrival time of the first necrophagous insects in all rats' cadavers.

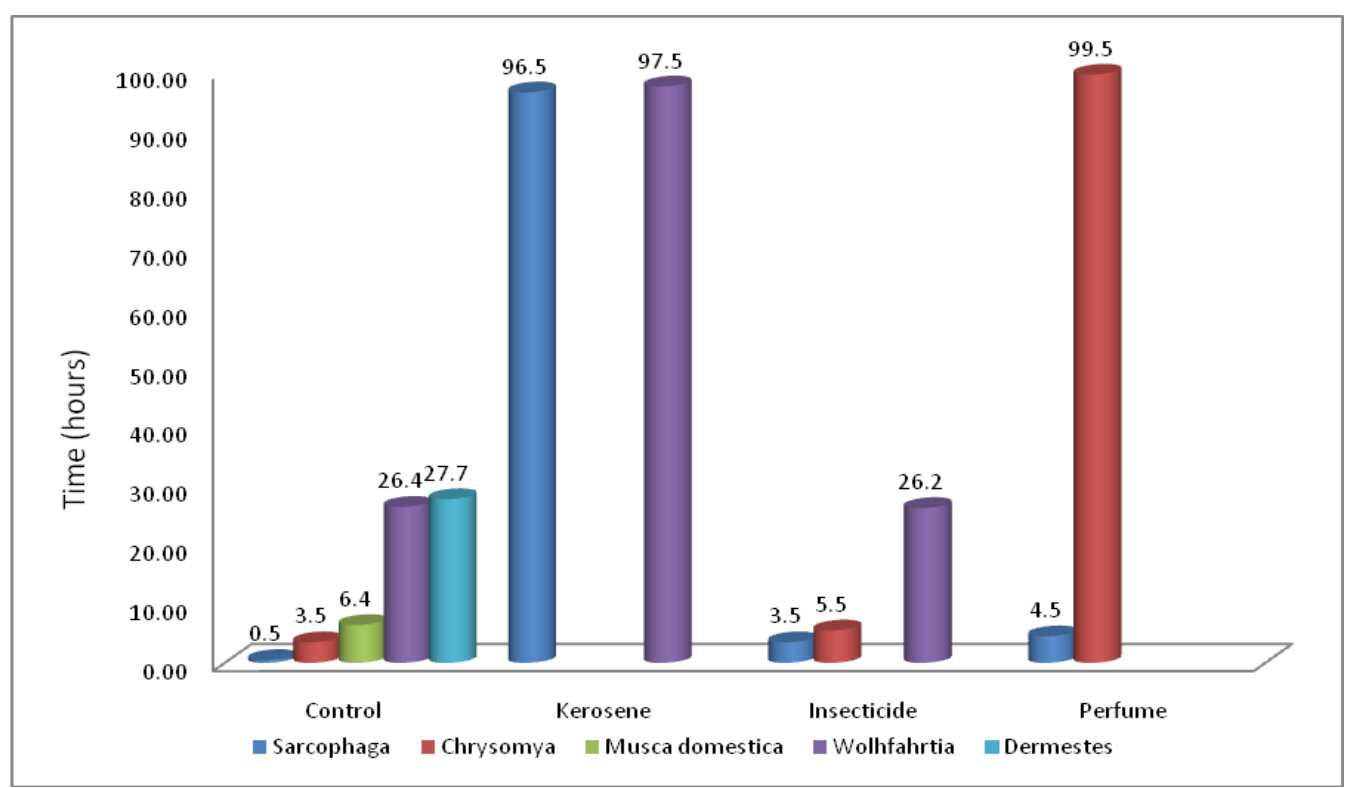

Figure (3): First arrival time of each insect species in all groups during the experiment in Assiut (Egypt).

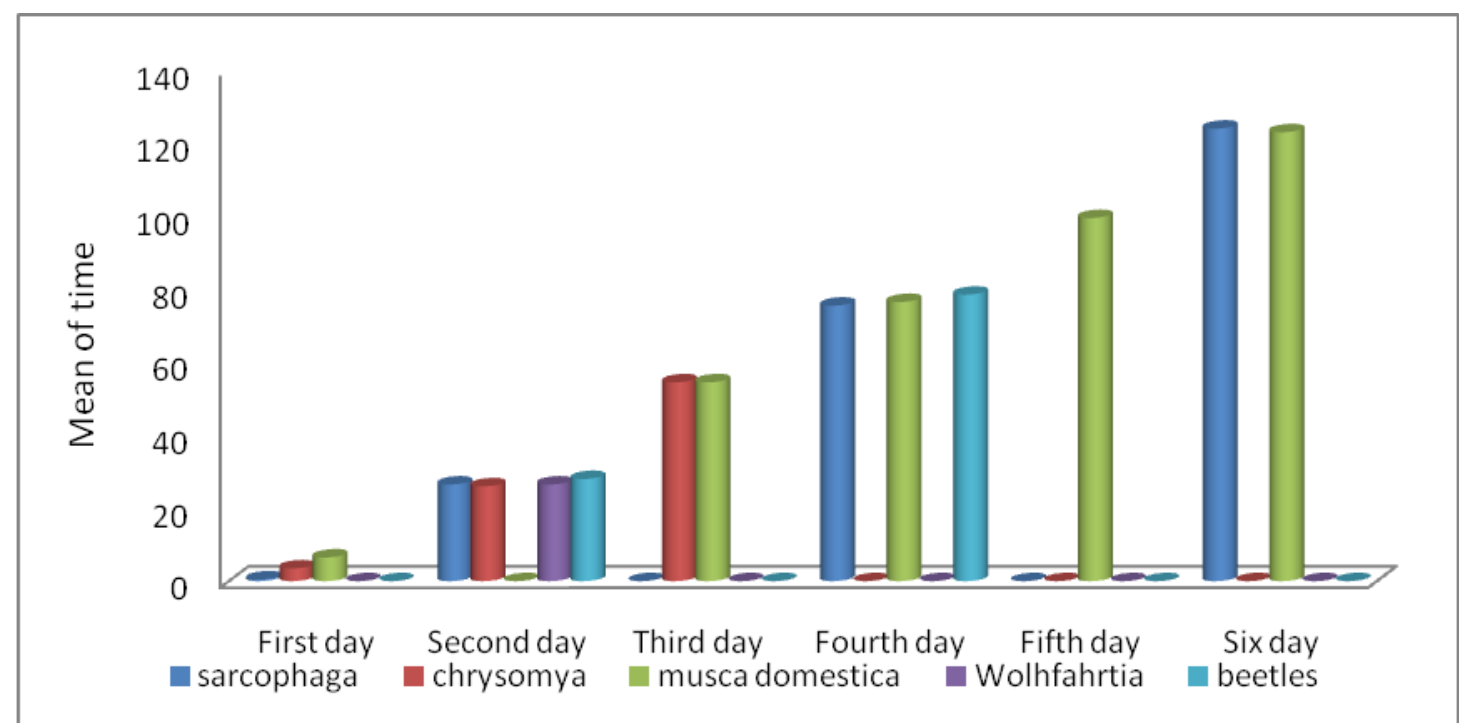

Figure (4): Time of arrival of each insect species appeared in control (Group 1). 


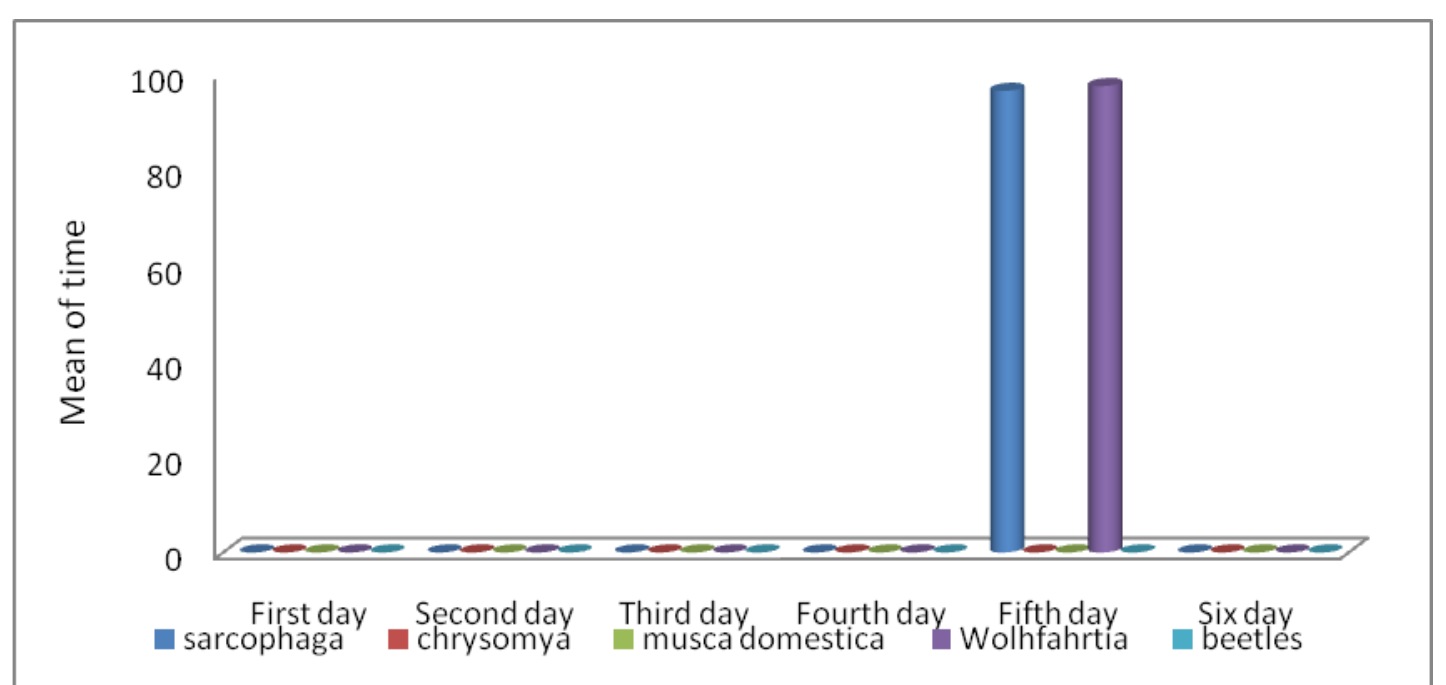

Figure (5): Time of arrival of each insect species appeared in kerosene poured rats (Group 2).

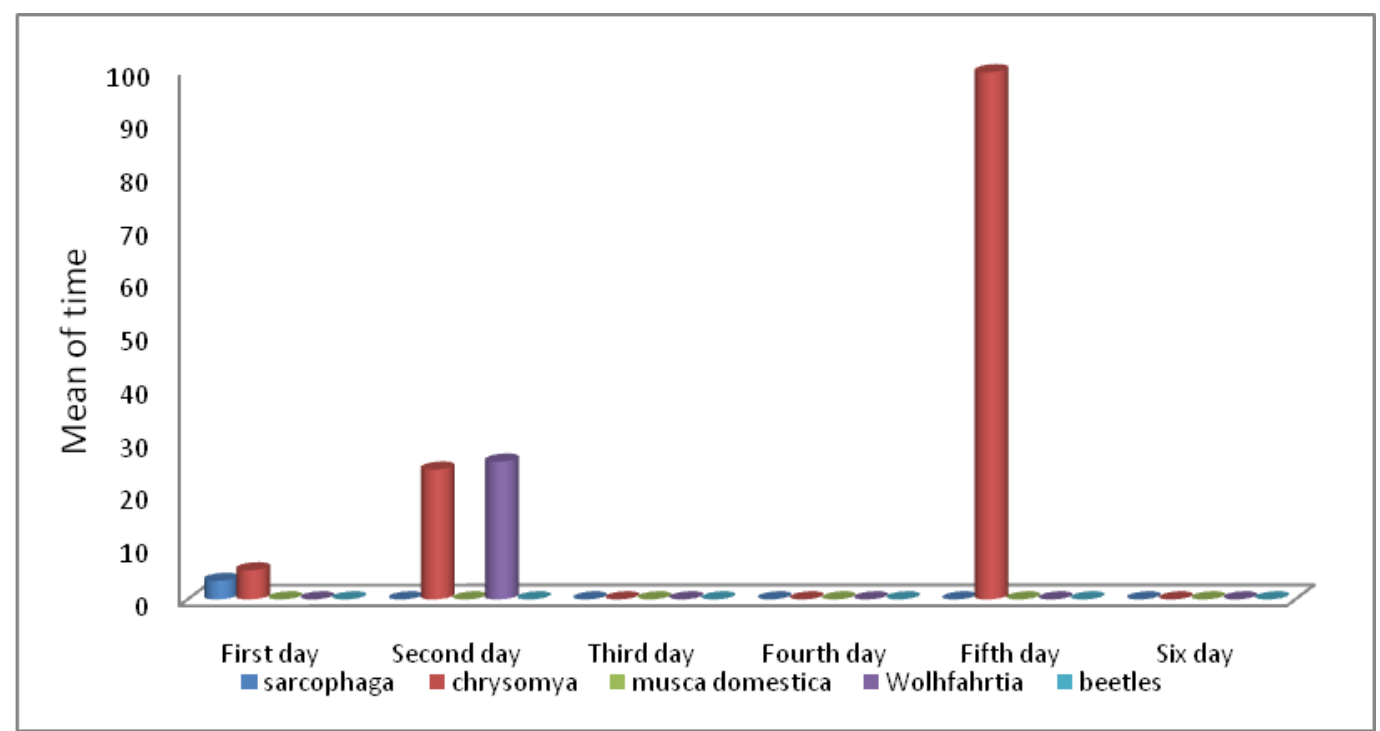

Figure (6): Time of arrival of each insect species appeared in insecticide poured rats (Group 3).

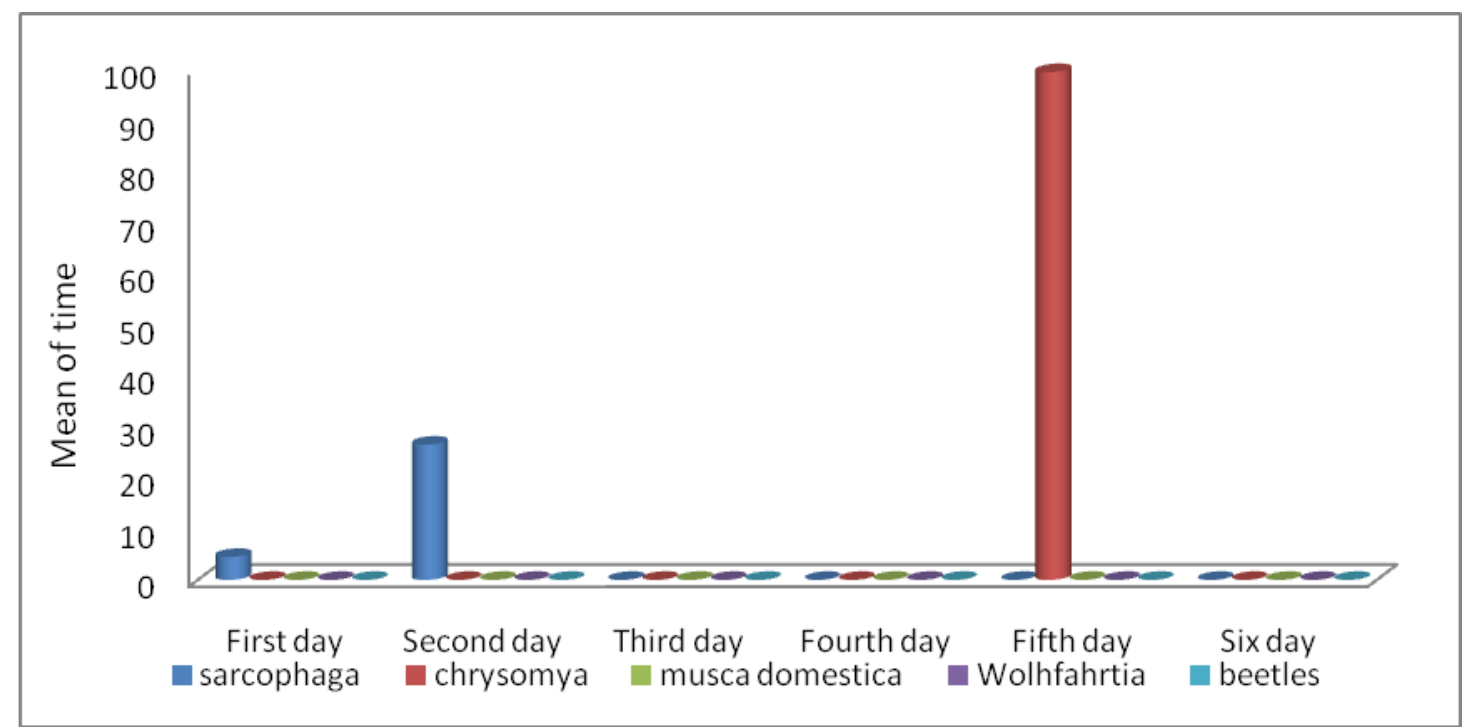

Figure (7): Time of arrival of each insect species appeared in perfumed poured rats (Group 4).

\section{Discussion}

Forensic entomology has been increasingly gaining international recognition in medicolegal discipline worldwide (Sukontason et al., 2007).
The present study provides a short field investigation on the response of necrophagous insects 
to small carrion cadavers poured with different household products.

Five genera of insects representing two orders and four families were found to be coexisted on both control and treated carcasses. Family Sarcophagidae represented by Sarcophaga haemorrhoidals and Wolhfahrtia sp., family Calliphoridae represented by Chrysomya albiceps, family Muscidae represented by Musca domestica and family Dermestidae represented by adult beetles of Dermestes frischii.

The succession of arthropod fauna observed on the carrion of the present study follows the same general pattern found in both tropical and temperate areas as stated by Galal et al. (2009): rapid invasion of specimens by adult Diptera (sarcophagidae and calliphoridae). It was followed by the appearance of Muscidae and adult coleopterans (beetles) during which the arthropod diversity reaches its maximum.

This agrees with that reported by Oliva (2001) in Argentina; who described families of Diptera as being the first to colonize cadavers and dominate in early stages of decomposition, whilst Coleoptera was the second. Varatharajan and Sen (2000) also stated that beetles colonize corpses later than the flies. As well as Wolff et al. (2001) observed that the first flies of Sarcophagidae and Muscidae arrived within 30 minutes and beetles after 2 days. Kyerematen et al. (2012) also reported that Diptera (flies) arrived within hours or few days at the most, followed by Coleoptera (beetles).

From the above mentioned data, the succession of arthropod fauna observed on the carrions can be explained by an adaptation to reduce competition or the fact that Dipterans are strong fliers and arrive at the site of the corpse earlier. Segura et al. (2009) also provided that different species usually appear and disappear one after the other, as a cadaver degrades, certain resources are used up and then become available to others whilst the changes occurring in the body favor one species first and then another.

Sarcophagidae in this study were represented by Sarcophaga haemorrhoidals and Wolhfahrtia sp. Sarcophaga haemorrhoidals was the only Sarcophaga species captured in this study. However Sarcophaga carnaria flies was recorded in Assiut by Attia (2002) and Galal et al. (2009) in spring and summer. Hegazi et al. (1991) and Tantawi et al. (1996) also found other Sarcophaga $s p$ in the studied seasons for two years duration.

Wolhfahrtia sp. adults were also detected in this study (spring season) unlike Tantawi et al. (1996) where Wolhfahrtia adults were absent in spring and present in summer. This variation in season activity might be due to great climatic differences between Assiut and Alexandria in spring and summer seasons (Moatamed, 2005).

Chrysomya albiceps one of the calliphoridae detected in this study is a well-known hemisynanthropic fly and generally described as a tropical and subtropical species (Hall and Smith, 1993). Chrysomya albiceps had been mentioned to occur in Egypt as one of the most important carrion breeding fly by Adham et al. (2001) and Attia (2002). Chrysomya albiceps was the dominant dipteran fly in the current study as it was captured in all experimental rats except in kerosene poured rats (group 2). This agreed with the study of Abd El-bar and Sawaby (2011), in El-Qalyubiya, where they found that the blowfly Chrysomya albiceps constituted most of collected samples.

Beetles belonging to one genera were collected, namely, Dermestes frischii. Its adults had been observed at $2^{\text {nd }}$ day on control only (group 1). This observation was in agreement with Tantawi et al. (1996). On the other hand, Rodriguez and Bass (1983); Early and Goff (1986); Grassberger and Frank (2004) studies, observed that Dermestidae were confined to later stages of decomposition and especially the dry stage.

This study aimed to evaluate the effect of some common household products (kerosene, insecticide and perfume) on first insect's arrival time. Charabidze et al. (2009) explained that the measurement of the repellent effect on a corpse by using the time to first arrival of flies is better than oviposition, as oviposition involved a more complex set of stimuli and responses.

In this study, three observable stages of decomposition were recognized in all rats' cadavers during the duration of experiment: fresh, bloat, wet decomposition. While in a study done by Galal et al. (2009) in Assuit city, four stages of decomposition were recognized (fresh, bloat, decay and dry). This may be explained by longer duration of study (20 days), higher temperature in summer $\left(37^{\circ} \mathrm{C}\right)$ and different type of specimen (human remain weighting 2$2.5 \mathrm{~kg}$ ). Kyerematen et al. (2012) also recorded four stages of decomposition in their study in Ghana, in a period of 28 days in February and March. While Wolff et al. (2001) recorded five stages of decomposition; fresh, bloating, active decay, advanced decay and dry remains, due to longer duration (207 days) in their study on Colombia.

The use of these common household products (kerosene, insecticide and perfume) didn't only affect the time of the first insect's arrival but also type of insects and stage of decomposition. The fresh decomposition stage ( $1^{\text {st }}$ day), manifested by discoloration of skin and first appearance of Sarcophaga haemorrhoidals immediately (within half an hour \pm S.D. $=0.1 \mathrm{hr}$ ) in control and delay of colonization for $3.5 \mathrm{~h}( \pm$ S.D. $=0.3 \mathrm{hr})$ in insecticide poured rats (group 3), $4.5 \mathrm{~h}( \pm$ S.D. $=0.4 \mathrm{hr})$ in perfume poured rats (group 4). Chrysomya albiceps appeared in rats of control and group 3, and Musca domestica in control rats only. This stage delayed in appearance to $2^{\text {nd }}$ day in kerosene poured rats (Group 2) without appearance of any insect. The bloat decomposition stage $\left(2^{\text {nd }}, 3^{\text {rd }}\right.$ days $)$, characterized by body swelling and inflation, which was obvious in group1 and gradual in groups 3, 4. This stage delayed in rats of group 2 to the $5^{\text {th }}$ day. Continuation the appearance of Sarcophaga haemorrhoidals in control rats, appearance of Wolhfahrtia in control and groups 2, 3, Chrysomya albiceps appeared in control and rats of group 3, while 
Musca domestica and Dermestes frischii were found in control rats only. The wet decomposition stage $\left(4^{\text {th }}\right.$ to $6^{\text {th }}$ days), liquefaction was observed in control and rats of groups 3, 4, with continuation of appearance of Sarcophaga haemorrhoidals ,Musca domestica and Dermestes frischii in control rats only, continuation the appearance of Chrysomya albiceps in rats of group 3 , while $1^{\text {st }}$ appearance of Chrysomya albiceps in rats of group 4.This stage hasn't been observed in rats of group 2 .

This agrees with Marchenko (1988), who clearly showed that compounds such as paint or gas dropped on clothing induce a delay in carrion colonization by a period twice as long as the control.

A study of Abd El-bar and Sawaby (2011) noticed insect species colonizing both control and test carcasses killed by organophosphorous injection were not different, indicating that organophosphorous were not masking the decomposition odors which were drawing the species to the bodies. They also found $48 \mathrm{~h}$ delay in blowfly colonization of test rabbit carcasses killed by organophosphorous injection. They observed distinct delay in decomposition stages, the decay of control carcasses was rapid while test carcasses did not decay completely, even 40 days post-killing.

As well as, Voss et al. (2008) observed a delay in appearance of Calliphoridae for 16-18 h, in carbon-monoxide-poisoned carcasses enclosed in vehicle, while the physical stages of decomposition was 3-4 days faster in the carcasses in enclosed vehicle due to higher temperatures there compared to external ambient temperature. El-Kady et al. (1994) found that neither arthropod invasion nor decomposition occurred on rabbits poisoned with arsenic oxide even after 11 months.

A study of the effect of chemical substances ( petrol, patchouli, $\mathrm{HCl}, \mathrm{NaOH}$, insecticide, citronella and lime), on the delay of colonization by necrophagous insects was carried out in 5 years duration ( September 1999, July 2001, July 2002, July 2003 and August 2003) by Bourel and his coworkers. They stated that $\mathrm{NaOH}$, citronella and lime had no or few effect on the delay of colonization and were similar to the controls. While Petrol, $\mathrm{HCl}$ and insecticide had an average retarding effect. Patchouli presented an important retarding effect (Bourel et al., 2004).

In contrast, in other experiment using $\mathrm{HCl}$, patchouli perfume, insecticide and kerosene placed on the rat carcass, the strongest effect was noted with $\mathrm{HCl}$ and patchouli perfume, which induced a mean colonization delay of $73 \mathrm{~h}($ S.D. $=46 \mathrm{~h})$ and $101 \mathrm{~h}$ $(\mathrm{S} . \mathrm{D} .=95 \mathrm{~h})$ respectively Charabidze et al., (2009).However the kerosene, very volatile in a very hot summer of the experiment, had no detectable repellent effect. It would seem that the effect of weather is an important factor in the degradation kinetic of tested products. Thus, high temperature and humidity could modify the kinetic of a substance's evaporation or fixation in animal tissues.

\section{Conclusion}

This study highlights the possibility to delay colonisation of a corpse by necrophagous insects simply by splashing substances on to the corpse. It seems that household products can be used to conceal or alter the odor associated with a cadaver and to induce a delay in the first arrival of necrophagous flies. Even if the precise estimation of the delay is difficult because it is also dependent on meteorological data, it is important to take it into account in forensic expertise. More studies are recommended to be carried out in different geographical situations and different habitats with the use of large scale different repellents to confirm the present study preliminary observations.

\section{References}

Abd El-bar M and Sawaby R (2011): A preliminary investigation of insect colonization and succession on remains of rabbits treated with an organophosphate insecticide in ElQalyubiya Governorate of Egypt. Forensic Sci. Int. 208 (1-3): e26-e30.

Adham F, Abdel M, Tawfik M et al., (2001): Seasonal incidence of the carrion breeding blowflies Lucilia sericata (Meigen) and Chrysomya albiceps (Wied.) (Diptera: Calliphoridae) in Abu-Rawash Farm, Giza, Egypt. Assiut Vet. Med. J. 49:377-383.

Anderson G (1998): Forensic Entomology: The use of insects in death investigations. www.rcmplearning.org. Accessed in: 22/2/2010.

Arnaldos M, García M, Romera E et al.,(2005): Estimation of postmortem interval in real cases based on experimentally obtained entomological evidence. Forensic Sci. Int. 149(1): 57-65.

Arnett R, Downie N and Jagues H (1980): How to know the beetles.3rd ed.: Wm.C. Brown Company. Dubuque, Iowa USA: pp.400- 416.

Attia R (2002): Studies on some cyclorraphous flies in Assiut Governorate. M.Sc. Thesis, Faculty of Medicine, Assiut University. Assiut.

Bourel B, Hedouin V and Gosset D (2004): Effect of various substances on the delay of colonization by necrophagous insects. (EAFE Congress). Proceeding the 2nd meeting of European Association for Forensic Entomology.London,2930/3/2004.www.eafe.org/Meeting_London_Fl ies.Accessed:12/6/2012.

Campobasso C and Introna F (2001): The forensic entomologist in the context of the forensic pathologist's role. Forensic Sci. Int. 120 (1-2): 132-139.

Campobasso C, Di Vella G and Introna F (2001): Factors affecting decomposition and Diptera colonization. Forensic Sci. Int. 120 (1-2): 1827. 
Centeno N, Maldonado M and Oliva A (2002): Seasonal patterns of arthropods occurring on sheltered and unsheltered pig carcasses in Buenos Aires Province (Argentina). Forensic Sci. Int. 126(1): 63-70.

Charabidze D, Bourel B, Hedouin V et al., (2009): Repellent effect of some household products on fly attraction to cadavers. Forensic Sci. Int. 189 (1-3):28-33.

Early M and Goff M (1986): Arthropod succession patterns in exposed carrion on the Island Of O'ahu, Hawaiian Islands, USA. J. Med. Entomol. 23 (5): 520-531.

El-Kady E, EssaY and Shalaby O (1994): Variations in the blow and flesh flies succession on rabbit carrions killed by different methods. J. Egypt. Ger. Soc. Zool. 13: 451-489.

Galal L, Abd-El-hameed S, Attia R et al., (2009): An initial study on arthropod succession on exposed human tissues in Assiut, Egypt. Mansoura J. of Forensic Med. Clin. Toxicol. XVII (1):55-74.

Gibson G and Torr S (1999): Visual and olfactory responses of Haematophagous Diptera to host stimuli. Med. Vet. Entomol. 13(1):2-23.

Grassberger M and Frank C (2004): Initial study of arthropod succession on pig carrion in central European urban habitat. J. Med. Entomol. 41(3): 511-523.

Greenberg B (1971): Ecology, classification and biotic association. In: Flies and Disease. Princeton University Press, Princeton N.J.USA. Vol. (1): pp.111-121.

Hall M and Smith K (1993): Diptera causing myiasis in man. In: Medical Insects and Arachnids. Lane R P and Crosskey R W (eds), Chapman \& Hall, London. pp.429-469.

Hegazi E, Shaaban M and Sabry E (1991): Carrion insects of the Egyptian western desert. J. Med. Entomol. 28(5): 734-739.

Kyerematen R, Boateng B and Twumasi A (2012): Insect diversity and succession pattern on different carrion types .J of Res. in Biol. 2(7): 683-690.

Marchenko M (1988): Medico-legal relevance of cadaver entomofauna for the determination of the time since death. Acta Med. Leg. Soc. Liege. 38(1): 257-302.

Moatamed A (2005): Ecosystems and its problems in Assiut governorate: A study in applied geography. Ph.D Thesis, Faculty of Medicine, Assiut University. Assiut.

Mosallam S (1980): Biological studies of some myiasis producing dipterous flies in Cairo. Ph.D
Thesis, Faculty of Medicine, Ain Shams University. Cairo.

Oliva A (2001): Insects of forensic significance in Argentina. Forensic Sci. Int. 120 (1-2):145154.

Rodriguez W and Bass W (1983): Insect activity and its relation ships to decay rates of human cadavers in east Tennessee. J. Forensic Sci. 28(2):423-432.

Segura N, Usaquén W, Sánchez M et al., (2009): Succession pattern of cadaverous entomofauna in a semi-rural area of Bogotá, Colombia. Forensic Sci. Int. 187(1-3): 66-72.

Shaumar N, Mohammed S and Mohammed S (1989): Keys for identification of species of family Calliphoridae (Diptera) in Egypt. J. Egypt Soc. Parasitol. 19(2):669-681.

Sukontason K, Narongchai P, Kanchai C et al., (2007): Forensic entomology cases in Thailand: a review of cases from 2000 to 2006. Parasitol Res. 101(5):1417-1423.

Tantawi T.I., El-kady E.M., Greenberg B. Et al., (1996): Arthropod succession on exposed rabbit carrion in Alexandria, Egypt. J. Med. Entmol., 33(4): 566-580.

VanLaerhoven S (2008): Blind validation of postmortem interval estimates using developmental rates of blow flies. Forensic Sci. Int. 180 (2-3):76-80.

Varatharajan R and Sen A (2000): Role of entomology in forensic sciences. Current Sci.78 (5):544546.

Voss S, Forbes S and Dadour I (2008): Decomposition and insect succession on cadavers inside a vehicle environment. Forensic Sci. Med. Pathol.4(1):22-32.

Wells J, Byrd J and Tantawi T (1999): Key to thirdinstar Chrysomyinae (Diptera:Calliphoridae) from carrion in the Continental United States. J. Med. Entomol. 36 (5): 638-641.

Wolff M, Uribe A, Ortiz A et al., (2001): A preliminary study of forensic entomology in Medellín,Colombia. Forensic Sci. Int. 120 (12):53-59.

Yones D, Attia R, Galal A et al., (2010): Identification of forensically important beetles on exposed human left over parts in Assiut Egypt During Spring / Summer Season. Assiut Medical J. 34 (1): $123-132$. 
الملخص العربي

\section{تأثير بعض المواد المنزلية (كيروسين، مبيد حشري وعطر) على استعمار مفصليات الأرجل على جثث الفئران}

\section{نجوى محمود غندور 1 و رشا عبد المنعم حسن عطية2}

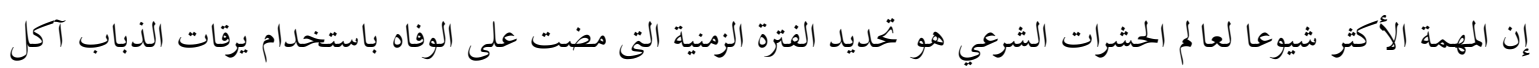

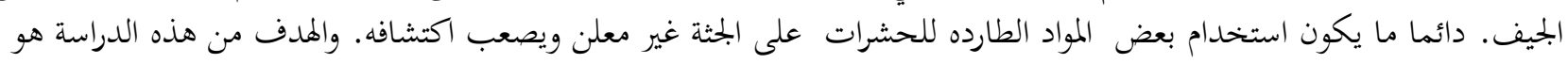

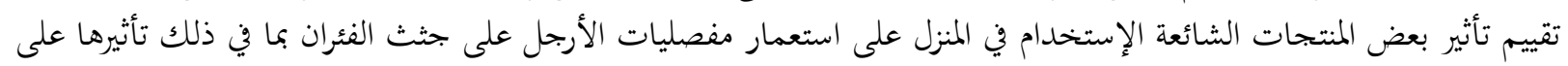

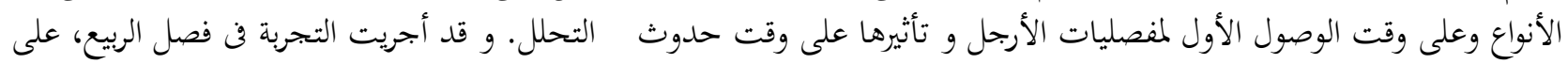

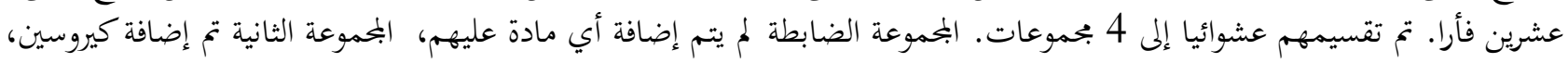

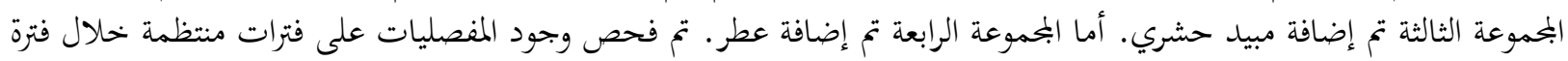

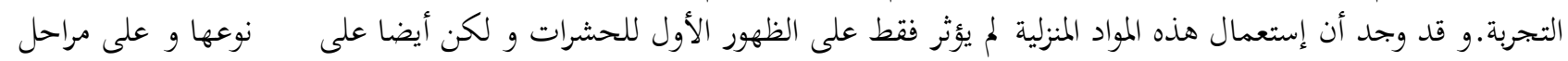

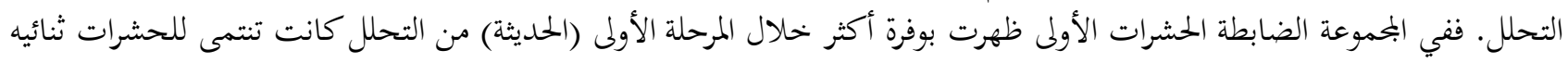

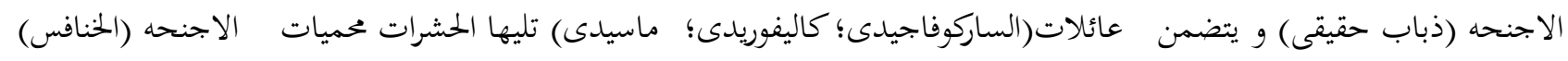

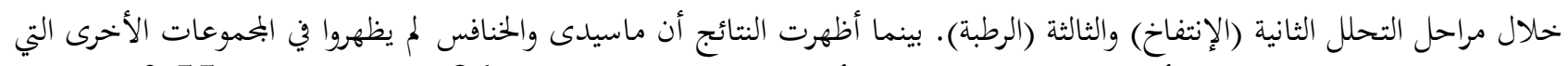

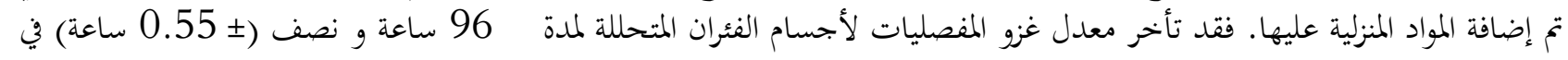

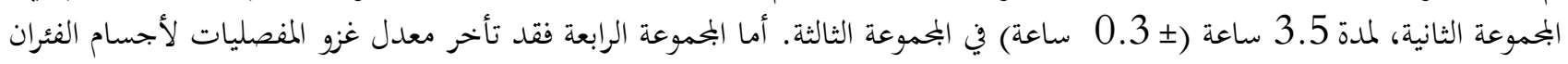

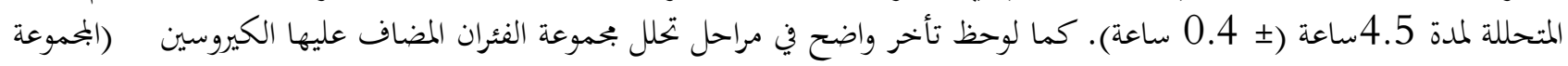

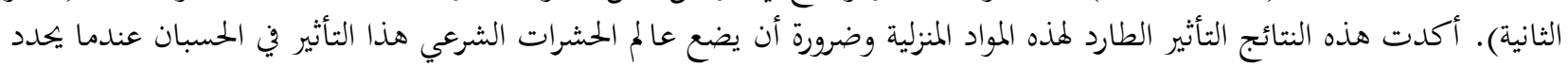
الفترة الزمنية التي مضت على الوفاة. 